\title{
Efektifitas Penyembuhan Luka Jahitan Episiotomi Dengan Konsumsi Telur Puyuh Rebus
}

\section{Acceleration Of Episiotomy Suture Healing By Consumption Of Boiled Quail Eggs}

\author{
Sari Widya Ningsih"1, Lolli Nababan ${ }^{2}$ \\ ${ }^{1,2}$ Sekolah Tinggi Ilmu Kesehatan Sapta Bakti Bengkulu Indonesia \\ ${ }^{1}$ sariwidya0303@gmail.com*; ${ }^{2}$ lollynbb@gmail.com \\ Tanggal Submisi: 19 Oktober 2020, Tanggal Penerimaan: 12 Januari 2021
}

\begin{abstract}
Abstrak
Tujuan Penelitian ini adalah untuk mengetahui pengaruh konsumsi telur puyuh rebus untuk percepatan penyembuhan luka jahitan episiotomi. Penelitian menggunakan data prime dengan sistem reeda scale pada kelompok kontrol dan perlakuan. Hasil analisis univariat dari 15 orang responden yang mengkosumsi telur puyuh rebus sembuh dalam waktu 5 hari sebanyak 11 Orang (73\%), Hasil Analisis Bivariat Dari 30 Responden, yang mengkosumsi makanan protein hewani seperti telur puyuh rebus akan mengalami penyembuhan luka perinium lebih cepat ( 15 orang) dibandingkan yang tidak mengkosumsi telur puyuh. Hasil $p$-value $=0,000$ yang berarti ada pengaruh kosumsi telur puyuh rebus terhadap penyembuhan luka perineum.
\end{abstract}

Kata Kunci : luka episiotomi, telur puyuh rebus, ibu nifas

\begin{abstract}
The purpose of this study was to determine the effect of consuming boiled quail eggs to accelerate the healing of episiotomy sutures. The study used prime data with a reeda scale system in the control and treatment groups. The results of univariate analysis of 15 respondents who consumed boiled quail eggs recovered within 5 days as many as 11 people (73\%), Bivariate Analysis Results From 30 respondents, who consumed animal protein foods such as boiled quail eggs would experience faster healing of perineal wounds (15 people) compared to those who did not consume quail eggs. The results of $\mathrm{p}$-value $=0.000$ which means that there is an effect of consuming boiled quail eggs on perineal wound healing.
\end{abstract}

Keywords: episiotomy wound, boiled quail eggs, postpartum mother

\section{PENDAHULUAN}

Kematian ibu adalah kematian seorang wanita terjadi saat hamil, bersalin, atau 42 hari setelah persalinan (masa nifas). Menurut World Health Organization (WHO) pada tahun 2014 memperkirakan 99\% kematian ibu akibat komplikasi kehamilan, proses kelahiran dan nifas. (Prawirohardjo, 2008) Mortalitas dan morbiditas pada wanita hamil, bersalin dan nifas adalah masalah besar di negara berkembang. Dimana dinegara-negara berkembang mempunyai rasio angka kematian ibu masih tinggi yaitu sebesar 450 kematian ibu per 100.000 kelahiran hidup jika dibandingkan dengan rasio angka kematian ibu di negara maju (Walyani, 2015)

Luka perineum adalah luka dikarenakan adanya robekan jalan lahir maupun karena episiotomi pada waktu melahirkan janin (Wiknjosastro, 2005). Dimana wanita yang melahirkan pervaginam sedikit banyak mengalami trauma seperti luka pada perineum akibat episiotomi, ruptur uteri atau laserasi perenium (Yuwanto, 2010). Persalinan dengan luka perineum apabila tidak ditangani secara efektif dapat menyebabkan perdarahan, infeksi 
sedangkan pada jangka waktu panjang dapat mengganggu ketidak nyamanan ibu dalam beraktifitas dan hubungan seksual (Mochtar, 2007).

Adapun faktor-faktor yang mempengaruhi kesembuhan luka perenium dibagi 2, yaitu: faktor internal (usia, cara perawatan, personal hygiene/kebersihan diri, over aktivitas, infeksi) dan faktor eksternal (gizi (nutrisi), tradisi atau lingkungan, pengetahuan, sosial ekonomi dan sarana prasarana, penanganan petugas pada saat persalinan dan kondisi ibu (Herawati).Pdf, n.d.), (Aji, 2015)

Penelitian (Ulmi Rifani.Pdf, n.d.) menyebutkan bahwa penerapan konsumsi telur ayam rebus terbukti dapat mengurangi penyembuhan luka jahitan perineum pada ibu nifas. Sejalan dengan penelitian E(Kebidanan et al., 2014), Dimana protein sangat berpengaruh dalam proses penyembuhan luka perineum karena penggantian jaringan yang rusak akan sangat membutuhkan protein untuk proses regenerasi sel baru. Protein bertanggung jawab sebagai zat untuk blok pembangun otot, jaringan tubuh, tetapi tidak dapat disimpan oleh tubuh, maka untuk tahap penyembuhan luka dibutuhkan asupan protein setiap hari (Maya Saputri \& Febiola, 2021), (Morison, 2007)

Sejumlah hasil penelitian telah membuktikan manfaat telur rebus dibutuhkan untuk kesembuhan luka jahitan perinium pada ibu nifas, mayoritas responden sembuh normal dengan waktu yang dibutuhkan antara 6-7 hari, lamanya waktu yang dibutuhkan untuk kesembuhan jahitan luka perineum terlihat nyata, waktu kesembuhan yang dibutuhkan ibu nifas yang tidak mengkonsumsi telur rebus rata-rata 7,4 hari. (Jan \& Masih, 2012) Terdapat pengaruh waktu kesembuhan luka jahitan perineum pada ibu nifas antara yang mengkonsumsi telur rebus dan yang tidak mengkonsumsi telur rebus. Hal ini dibuktikan bahwa harta t hitung lebih kecil dari t tabel $(-4,869$ kurang dari -2,042) sehingga Ho diterima dan Ha ditolak. Jadi terdapat perbedaan secara signifikan waktu kesembuhan yang dibutuhkan ibu nifas yang tidak mengkonsumsi telur rebus dan yang tidak mengkonsumsi telur rebus. Waktu kesembuhan ibu nifas yang mengkonsumsi telur rebus lebih cepat 1,7 hari (Notoadmojo, 2010). Tujuan Penelitian ini yaitu untuk mengetahui waktu percepatan penyembuhan luka perineum dengan penerapan konsumsi telur puyuh rebus, dan untuk mengetahui efektifitas hasil penerapan konsumsi telur puyuh rebus untuk percepatan penyembuhan luka perineum setelah diberikan penerapan.

\section{METODE PENELITIAN}

Penelitian ini menggunakan rancangan penelitian studi eksperimen dengan Nonequivalent Control Group Design yaitu peneliti menentukan subjek penelitian ke dalam kelompok eksprimen atau kelompok kontrol dengan prosedur tidak randomisasi, dalam desain ini, baik kelompok ekperimental maupun kontrol dibandingkan, kelompok tersebut dipilih dan ditempatkan tanpa melalui random. Jumlah Sampel yaitu 30 orang ibu nifas dengan luka episiotomi derajat II. Penelitian ini menggunakan data primer (data ibu nifas dan observasi penyembuhan luka setiap $0-7$ Hari setelah post partum menggunkan sistem reeda scale pada kelompok kontrol dan perlakuan. (Notoadmojo, 2010)

Pada penelitian ini populasinya adalah ibu post partum dibagi menjadi 2 kelompok. Kelompok pertama adalah kelompok diberikan plasebo dan kelompok kedua yang diberikan Telur Puyuh Rebus. Teknik pengumpulan dilakukan dengan observasi lapangan dengan pengamatan, pengukuran dan pencatatan berkaitan dengan pengukuran percepatan luka perenium. Instrumen yang digunakan untuk observasi adalah reeda scale. Kemudian hasilnya dibandingkan antara kelompok kontrol dan kelompok eksperimen.

Jumlah Sampel yaitu 30 orang ibu nifas dengan luka episiotomi derajat II. Penelitian ini menggunakan data primer (data ibu nifas dan observasi penyembuhan luka setiap 0 - 7 Hari, dengan rincian 15 orang ibu post partum sebgai kelompok kontrol dan 15 orang ibu post partum sebagai kelompok ekperimen dengan teknik pengambilan sampel 
secara consecutive sampling yaitu semua ibu post partum yang bersalin di Bidan Praktik Mandiri (BPM) yang memenuhi kreteria penelitian dijadikan sampel. Setelah data terkumpul, dilakukan analisis univariat atau deskripsi maupun analisis bivariat dengan uji $\mathrm{T}$ tidak berpasangan, sedangkan kriteria ekslusi ibu yang tidak bersedia menjadi responden.

\section{HASIL DAN PEMBAHASAN}

Tabel 1. Distribusi Frekuensi Pengaruh Kosumsi Telur Puyuh Rebus Terhadap Percepatan Penyembuhan Luka Perenium pada ibu Nifas di Wilayah Kerja Basuki Rahmad 2019

\begin{tabular}{|c|c|c|c|c|c|c|c|c|}
\hline \multirow{3}{*}{$\begin{array}{l}\text { Konsumsi telur } \\
\text { puyuh rebus }\end{array}$} & \multicolumn{4}{|c|}{ Penyembuhan luka perinium } & \multirow[t]{2}{*}{ Total } & & \multirow[t]{2}{*}{$\mathrm{P}$} & \multirow[t]{2}{*}{$\alpha$} \\
\hline & \multicolumn{2}{|c|}{ Cepat } & \multicolumn{2}{|c|}{ Lambat } & & & & \\
\hline & $\mathrm{f}$ & $\%$ & $\mathrm{f}$ & $\%$ & $\mathrm{f}$ & $\%$ & & \\
\hline $\mathrm{Ya}$ & 11 & 73 & 4 & 27 & 15 & 10 & 0,022 & 0,005 \\
\hline Tidak & 1 & 7 & 14 & 93 & 15 & 10 & & \\
\hline Total & 12 & & 18 & & 30 & 10 & & \\
\hline
\end{tabular}

Berdasarkan tabel 1, dari 15 orang responden ibu nifas yang mengkosumsi telur puyuh rebus paling banyak sembuh dalam waktu 5 hari sebanyak 11 orang (73\%) dan 6 Hari sebanyak 4 orang $(27 \%)$ dengan penyembuhan luka perenium lebih cepat, sedangkan 15 orang responden ibu nifas yang tidak mengkosusmsi telur puyuh rebus paling banyak sembuh $>7$ hari sebanyak 14 orang (93\%) dengan penyembuhan luka perenium lambat, Adapun faktor-faktor yang mempengaruhi kesembuhan luka perenium dibagi 2, yaitu: faktor internal (usia, cara perawatan, personal hygiene/kebersihan diri, over aktivitas, infeksi) dan faktor eksternal (gizi (nutrisi), tradisi atau lingkungan, pengetahuan, sosial ekonomi dan sarana prasarana, penanganan petugas pada saat persalinan dan kondisi ibu (Herawati).Pdf, n.d.), (INDAH TRIANINGSIH.Pdf, n.d.). Meskipun banyak faktor yang mempengaruhi, tetapi menjaga asupan nutrisi protein tinggi dengan putih telur lebih dominan untuk pemenuhan kebutuhan protein dalam tubuh (Kebidanan et al., 2014). Hasil penelitian (Ulmi Rifani.Pdf, n.d.) menyebutkan bahwa penerapan konsumsi telur ayam rebus terbukti dapat mempercepat penyembuhan luka jahitan perineum pada ibu nifas. Sejalan dengan penelitian (Henny Novita.Pdf, n.d.). Dimana protein sangat berpengaruh dalam proses penyembuhan luka perinium karena penggantian jaringan yang rusak akan sangat membutuhkan protein untuk proses regenerasi sel baru. Protein bertanggung jawab sebagai zat untuk blok pembangun otot, jaringan tubuh, tetapi tidak dapat disimpan oleh tubuh, maka untuk tahap penyembuhan luka dibutuhkan asupan protein setiap hari. Dalam telur rebus mengandung zat colin yang mempunyai efek memperbaiki sel tubuh yang rusak (Maya Saputri \& Febiola, 2021), (Maya Saputri \& Febiola, 2021) 
Tabel 2. Analisis Perbedaan Rata - Rata Waktu Penyembuhan Luka Perenium pada kelompok intervensi dan control di Wilayah Kerja Basuki Rahmad 2019

\begin{tabular}{l|c|c|c|c}
\hline Kelompok & $\mathrm{n}$ & Mean & SD & $p$ value \\
\hline intervensi & 15 & 5,4667 & 0,51640 & 0,000 \\
\hline kontrol & 15 & 6,9333 & 0,25820 & \\
& & & &
\end{tabular}

Berdasarkan tabel 2, terdapat pengaruh kosumsi telur puyuh rebus pada ibu nifas dengan penyembuhan luka perenium. Dari 30 Responden yang diteliti, yang mengkosumsi makanan protein hewani seperti telur puyuh rebus akan mengalami penyembuhan luka perenium lebih cepat (15 orang) dibandingkan yang tidak mengkosumsi telur puyuh Perenium puyuh rebus. rata- rata penyembuhan luka perenium kelompok eksperimen 5,4 Hari sedangkan penyembuhan luka perenium pada kelompok kontrol adalah 6,9 Hari. Hasil $p$-value $=0,000$ yang berarti ada pengaruh terhadap penyembuhan luka perineum terhadap percepatan percepatan penyembuhan luka perenium. Selisih waktu yang dibutuhkan ibu nifas untuk kesembuhan luka jahitan perenium adalah 1,5 hari lebih cepat hari dibandingkan ibu yang tidak mengkosumsi telur puyuh rebus dan mengalami perbedaan secara signifikan.

Sejumlah hasil penelitian (Naskah Publikasi_Yeni Komala_1610104252.Pdf, n.d.) telah membuktikan manfaat telur rebus dibutuhkan untuk kesembuhan luka jahitan perinium pada ibu nifas, mayoritas responden sembuh normal dengan waktu yang dibutuhkan antara 6-7 hari, lamanya waktu yang dibutuhkan untuk kesembuhan jahitan luka perineum terlihat nyata, waktu kesembuhan yang dibutuhkan ibu nifas yang tidak mengkonsumsi telur rebus rata-rata 4,7 hari.(VENTI WILIANI.Pdf, n.d.) Terdapat pengaruh waktu kesembuhan luka jahitan perineum pada ibu nifas antara yang mengkonsumsi telur rebus dan yang tidak mengkonsumsi telur rebus. Hal ini dibuktikan bahwa nilai t hitung lebih kecil dari t tabel $(-4,869$ kurang dari $-2,042)$ sehingga Ho diterima dan Ha ditolak. Jadi terdapat perbedaan secara signifikan waktu kesembuhan yang dibutuhkan ibu nifas yang tidak mengkonsumsi telur rebus dan yang tidak mengkonsumsi telur rebus. Waktu kesembuhan ibu nifas yang mengkonsumsi telur rebus lebih cepat 1,7 hari (Notoadmojo, 2010).

Penelitian ini Sejalan dengan penelitian (Ulmi Rifani.Pdf, n.d.), berdasarkan hasil penelitiannya tentang Setelah mengkonsumsi telur ayam rebus 2 diantara 3 partisipan mengalami penyembuhan luka perineum. Hal ini tampak dari penerapan yang dilakukan selama 1-7 hari post partem pada hari ke 2. Penyembuhan tersebut termasuk dalam kategori luka sembuh cepat dan luka sembuh lambat.(HELMI KARINDA- SKRIPSI 1 - for Perpus.Pdf, n.d.)

Penelitian (Prasetya.Pdf, n.d.) menunjukan Pelaksanaan inovasi penyembuhan luka dengan menggunakan air rebusan daun sirih merah dan mengkomsumsi telur rebus didapatkan hasil penyembuhan luka pada Ny. K memerlukan waktu 6 hari. Hal ini ditunjukkan bahwa luka sudah kering dan jaringan-jaringan pada luka perineum sudah menyatu sempurna.(WENI TRI PURNAMI.Pdf, n.d.)

Masalah yang sering muncul pada ibu dengan luka perineum yaitu nyeri pada luka jahitan, aktivitas terganggu, masih takut buang air besar (BAB) dan buang air kecil (BAK) dan belum mengetahui cara perawat luka dengan baik sehingga terjadi infeksi ditandai 
keluarnya lokea purulenta (Herawati).Pdf, n.d.). Kebutuhan yang diberikan pada ibu nifas dengan luka perineum yaitu kebutuhan pemeriksa luka ibu segera sembuh agar terhindar dari infeksi, kebutuhan ibu yaitu Jelaskan hasil pemeriksaan kepada pasien dan keluarga pasien, pemberian nutrisi mengandung protein tinggi, personal hygiene, cara perawatan luka, pemberian obat antibiotik, mobilisasi (Herawati).Pdf, n.d.).

\section{SIMPULAN}

Berdasarkan hasil penelitian dan pembahasan dapat ditarik kesimpulan penyembuhan luka perenium pada ibu nifas di Wilayah Kerja Puskesmas Basuki Rahmad yang mengkosumsi telur puyuh rebus lebih cepat dibandingkan dengan yang tidak mengkosumsi telur puyuh rebus Yaitu Selisih waktu y (Placeholder1)ang dibutuhkan ibu nifas untuk kesembuhan luka jahitan perenium adalah 1,5 hari lebih cepat hari dibandingkan ibu yang tidak mengkosumsi telur puyuh rebus dan mengalami perbedaan secara signifikan, dan terdapat Pengaruh kosumsi telur puyuh rebus terhadap penyembuhan luka perenium pada ibu nifas di wilayah kerja Basuki Rahmad.

\section{SARAN}

Berdasarkan hasil penelitian yang telah dilakukan, ada beberapa saran yang dapat diberikan, yaitu hasil penelitian ini dapat dijadikan data dasar bagi peneliti selanjutnya terkait masalah gizi pada ibu nifas dengan penyembuhan luka perineum atau ibu nifas dengan lama penyembuhan luka perineum, dan hasil penelitian ini dapat dijadikan edukasi untuk kepentingan program khususnya terkait pemantauan konsumsi makan telur Puyuh rebus pada ibu nifas terhadap penyembuhan luka perineum di Puskesmas wilayah Kerja Puskesmas Basuki Rahmad

\section{REFERENCE}

Aji. (2015). Derajat Laserasi Perinium.

HELMI KARINDA-SKRIPSI 1 - for perpus.pdf. (n.d.).

Henny Novita.pdf. (n.d.).

herawati).pdf. (n.d.).

INDAH TRIANINGSIH.pdf. (n.d.).

Jan, A., \& Masih, E. D. (2012). Development and Quality Evaluation of Pineapple Juice Blend with Carrot and Orange juice. International Journal of Scientific and Research Publications, 2(8), 2250-3153. www.ijsrp.org

Kebidanan, A., Husada, G., Dukuh, J., Baru, P., \& Pada, H. (2014). TERHADAP PENYEMBUHAN LUKA PERINEUM IBU NIFAS Endang Buda Setyowati * Pendahuluan: Masa nifas merupakan masa pemulihan organ reproduksi yang mengalami perubahan selama kehamilan dan persalinan, seperti halnya robekan perineum yang terjadi hampir semua pe. 110, 16-24.

Maya Saputri, E., \& Febiola, E. (2021). Pengaruh Telur Rebus Dalam Penyembuhan Luka Perenium Pada Ibu Nifas Di Klinik Pratama Arrabih Tahun 2020. Prosiding Hang Tuah Pekanbaru, 67-74. https://doi.org/10.25311/prosiding.vol1.iss1.61

Mochtar, R. (2007). Sinopsis Obstetri Fisiologi dan Patologi. Kedoktran EGC.

Morison. (2007). Manajemen Luka. EGC.

Naskah Publikasi_Yeni Komala_1610104252.pdf. (n.d.).

Notoadmojo. (2010). Metodelogi Penelitian Kesehatan. Rineka Cipta.

prasetya.pdf. (n.d.).

Prawirohardjo. (2008). Profil Kesehatan. Yayasan Bina Pustaka.

ulmi rifani.pdf. (n.d.).

VENTI WILIANI.pdf. (n.d.). 
Walyani. (2015). Asuhan Kebidanan Pada Kehamilan. Pustaka Baru Press. WENI TRI PURNAMI.pdf. (n.d.).

Wiknjosastro. (2005). Ilmu Kebidanan. Yayasan Bina Pustaka.

Yuwanto. (2010). Pemanfaatan Kerabang Telur. Universitas Gajah Mada. 